\title{
Meta
}

Journal des traducteurs

Translators' Journal

\section{MUNDAY, Jeremy, ed. (2009): The Routledge Companion to \\ Translation Studies, revised edition, Oxon: Routledge, 285 p.}

\section{Janine Oliveira, José Endoença Martins et Orlanda Miranda Santos}

Volume 57, numéro 3, septembre 2012

URI : https://id.erudit.org/iderudit/1017094ar

DOI : https://doi.org/10.7202/1017094ar

Aller au sommaire du numéro

Éditeur(s)

Les Presses de l’Université de Montréal

ISSN

0026-0452 (imprimé)

1492-1421 (numérique)

Découvrir la revue

Citer ce compte rendu

Oliveira, J., Martins, J. E. \& Santos, O. M. (2012). Compte rendu de [MUNDAY, Jeremy, ed. (2009): The Routledge Companion to Translation Studies, revised edition, Oxon: Routledge, 285 p.] Meta, 57(3), 838-841.

https://doi.org/10.7202/1017094ar d'utilisation que vous pouvez consulter en ligne. 
he fails to mention its Chinese originator G. S. Hu (a professor of translation studies from Tsinghua University, China). And the seven Chinese scholars briefly quoted in the book are just for a supplementary reinforcement of the ideas put forward by western theorists.

XiangJun Liu Shanghai University of Finance \& Economics, Shanghai, China

\section{NOTES}

1. Opinions vary as to the category the German functional theories of translation belong to. Here we follow Munday (2001: 2) by putting them under the linguistic perspective though Hermans (2007: 90), for example, treats them as a functionalist approach parallel to the linguistic approach.

2. Of course, variations are not limited to simplification. There are also some shifts of emphasis and/or amplifications. For example, in Section 1 of Chapter 2 (corresponding to Munday's Chapter 2), Zhang uses translation principles instead of Munday's degree of systematicity of translation thought (Munday 2001: 24-27) as the clue to thread through the discussions of Dryden, Dolet, Tytler and Savory. Here only Savory is Zhang's addition.

\section{REFERENCES}

Hermans, Theo (2007): Literary Translation. In: Piotr Kuniwczak and Karin Littau, eds. A Companion to Translation Studies, Clevedon/ Buffalo/Toronto: Multilingual Matters Ltd., 77-91.

Munday, Jeremy (2001): Introducing Translation Studies: Theories and Applications, London/ New York: Routledge.

Munday, Jeremy, ed. (2009): The Routledge Companion to Translation Studies, revised edition, Oxon: Routledge, 285 p.

This volume of the series Language Studies and Linguistics, addressed to students, researchers, and professionals of translation, brings to the fore an authoritative voice on interfaces among linguistics, context, culture, politics, ethics, cognitive theories, technology, interpreting and audiovisual translation. Its contributors offer the readers invaluable insights into translation studies, "providing," in editor Munday's words, "an overview, a definition of key concepts, a description of major theoretical work and an indication of possible avenues of development" (p. 1).

The volume opens with an introductory chapter - Munday's Issues in Translation Studies - which brings a brief history of translation from
Marcus Tullius Cicero, the Roman rhetorician and orator, to St Jerome, the translator of the Bible. Munday calls attention to the strategies adopted by these translators and their annotated comments on their translating work. He brings historical texts and references into the scene with a view to guiding the reader towards the influential contribution of classical translators, claiming that "persistent revisiting of such writings has transfused translation studies in recent decades" (p. 4).

Munday examines Holmes's insightful contribution to the field with his naming the area Translation Studies, in 1972, a designation still in use today to refer to the disciplinary field established in early 70s. Considering the task of defining translation "a notoriously slippery action" (p. 6) Munday concentrates on "the ambit of translation" with its three aspects: "(1) the process of transferring a written text from SL to TL, conducted by a translator, or translators, in a specific socio-cultural context; (2) the written product, or TT, which results from that process and which functions in the socio-cultural context of TL; (3) the cognitive, linguistic, visual, cultural and ideological phenomena which are integral part of (1) and (2)" (p. 7). Despite its inclusiveness, Munday concedes the limitation of his proposed meaning for the term, suggesting that "such definitions still do not answer the question of the limits on translation and the boundaries between translation, adaptation, version, transcreation, etc. that have key implication for the criteria by which the target text is judged" (p. 7).

Additionally, Munday focuses on the roles cultural studies play in translation. He refers to the relevance of Bassnet and Lefevere's (1990) expression cultural turn, mentioning the shift that the term has caused to the research paradigms, and the resulting consequences on the notion of ST-TT equivalence, on the agents of translation and interpreting, and on fragmentation of the discipline.

Munday enlarges the scope of the chapter with the "challenges to perceptions of translation," not only insisting on the fact that "translation is an intercultural phenomenon" (p. 18), but also on the idea that the cultural turn ushered in a stream of investigation that transformed the discipline and what is understood as translation, thus aligning himself with Tymoczko's (2006) insistence on "the need to challenge presuppositions that have dominated the discipline" (p. 18). Additionally, he presents a brief summary of the volume with the content of each chapter and contributor's thoughts, and the role of key concepts at the end of the book and their connection with the ideas discussed by researchers in general and the contributors in particular.

Chapter two, Newmark's The linguistic and communicative stages in translation theory, initially 
looks at the different phases translation theory has gone through from the 1950's to 2000's, namely the linguistic, communicative, functionalist and ethic/ aesthetic ones, later concentrating on the linguistic and communicative one. Nida (1964) is, here, referred to as the most influential world figure in translation because he has created the first theory of communicative translation, putting forward the notion of functional equivalence so as to establish a distinction between functional equivalence and formal correspondence.

Newmark closes his chapter with a few comments on both the functionalist and the ethical/ aesthetic phases. He refers to the functionalist one as a translational shift from academic to "real world" texts. With regard to ethical/aesthetic stage, he ponders that translators preferably deal with official documental texts and serious literary works. Advising us that the translator's responsibility lies in seeking truth, New mark insists on the argument that the professional's work is to be attentive to the details of appropriate information, with the help of footnotes when necessary. The contributor invokes the Universal Declaration of Human Rights to defend the importance of truth and respect for the reader of translated texts.

Chapter three, Hatim's Translation Text in Context, looks at various communicative resources, examining them specifically from the vantage point of the translators. A translator and researcher in Applied Linguistics himself, Hatim tries to "disentangle" some of the terminological confusion involving communication from the perspective of the translator. In this context, he considers the need to discuss language processing models, among them, "text linguistics (Beaugrande, 1980), systemic-functional linguistics (Halliday, 1985/94; Halliday and Matthiessen, 2004), critical discourse analysis (Fairclough, 1989/2001, 2003), and contrastive rhetoric (Connor, 1986)" (p. 37).

In his analysis of the relation between text and context, Hatim says: "contexts tend to shape and are in turn shaped by texts" (p. 37). Regarding text-context relation, he copes with textualization in terms of production and reception of texts, defining textualization, then, as being "a process which impinges on both the production and reception of texts and which at one and the same time involves a set of procedures (i.e. strategies) and a diverse range of products (artifacts) generically known as 'texts"' (p. 37). He discusses register, text, discourse and genre from the perspective of Applied Linguistics, aiming at highlighting the kind of influences they may have on the translation process. He writes: “(..) the 'field' (or subject matter), the 'tenor' (related to level formality) and the 'mode' (involving various aspects of textuality such as cohesion) collectively make up the register membership of a text" (p. 39). Hatim suggests that, within Translation Studies, proponents of skopos theory like Vermeer $(1978 ; 1989)$ show good examples of how the field dynamics utilizes traditional register analysis to investigate minimal units of translation. He sums up: "discourse- and register-based analysis assists in uncovering and understanding the attitudes conveyed and, when used in translation practice, is a valuable tool in enabling these attitudes to be communicated appropriately in the target text” (p. 53).

In chapter 4 , Translation as a Cognitive Activity, considering the relevance of cognitive approaches to translation, Albir and Alves bring to discussion "six of [its] most representative models" (p. 54), together with translation competence (TC) and empirical-experimental research within a recent field designated by Muñoz (2007) as cognitive translation studies (CTS). These six models address interpretive theory of translation model, Bell's linguistic and psycholinguistic model, Kiraly's sociological and psycholinguistic model, Wilss' translation as a decision-making type of behavior, Gutt's relevance-theoretic approach to translation and finally Gile's effort model. Additionally, Albir and Alves argue that translation competence contributes to translators' and interpreters' carrying out of cognitive operations.

With regard to expert knowledge Albir and Alves focus on how "the gathering of data on translation processes and translation competence" can mutually cooperate in dealing with written translation and interpreting. They close the essay evaluating the years to come within research on written translating and interpreting, suggesting that the borrowing of tools from other disciplines like psychology can be compensated by redefinition of experimental designs and replication of studies.

In chapter 5, Translation as Intercultural Communication, Katan looks at translation as a communicative interaction between different cultures, a view that continues debatable due to the difficulty to establish clear-cut definition of culture. Applying the metaphor of the iceberg to culture, Katan argues that two views are possible: like an iceberg, culture has a visible part and a hidden one. Intervention on the visible or the invisible aspects of culture depends on the translator's interest on the top or the bottom of the iceberg. Considering culture a system of frames that comprise what is visible and what is invisible, Katan comes up with three types of culture - technical, formal and informal - each of them projecting a specific view of translation.

At last, Katan disregards translator's deliberate intervention to restate his beliefs in the translator who is, in fact, a cultural mediator, making efforts to negotiate the "constant state of flux" that translation allows to take place between specific 
cultures. On this intercommunicating level, the translator, as a bicultural subject, moves toward "intercultural sensitivity," an ability that allows him to (1) generate many but (2) select one viable text.

Hermans's contribution in chapter six, entitled Translation, Ethics and Politics, brings to the reader's consideration the aspects that energize Translation Studies with the incorporation of power-oriented perspective of ethical, political and ideological views in TS. Considering ethical concerns and political orientation, these new perspectives propose a view of translation that has much to do with the translator's deliberate interventions. A step forward in relation to the 70 's, the 80 's makes itself “a self-reflexive turn in translation studies" (p. 94). The phenomenon covers a great deal of scholars and contributions. Lefevere's key concept "patronage," for example, emphasizes patrons' economic and political interests in deciding that ideology should prevail over poetics, literature and language. Besides Lefevere's "patronage," other cases are Brazilian de Campos's "transcreation," a concept which proposes, "on its own terms and for its own purposes" (p. 103), the ingestion of the colonial culture and foreignizing attitudes of Spivak, Appiah and Venuti.

Hermans's analysis covers the 1990's, suggesting that both gender and post-colonial studies join translation studies with the previous contributions. He argues that women translation scholars and practitioners advocate reparative perspectives of translation. Similarly, post-colonial professionals in the field tend to work as repairers or "re-enunciators." Here, emphasis on "the dynamics of textual interweavings" (p. 102) connects translation to hybridity and rhizome, pointing out to cultural and linguistic in-betweenness implied by both concepts. Hermans insists, then, that in-betweenness in translation strengthens Cronin's idea, which considers translation as a cultural phenomenon, able to "increase the totality of humanity's knowledge base without undermining cultural specificity" (p. 105), by advocating "micro-cosmopolitanism."

Chapter seven, Hartley's Technology and Translation, opens with the statement that, in the 1990's, translation as a commercial activity has become a global business, whose growth has entirely taken world's commerce, citing Boucau (2006). Hartley lists some of the causes of this growth: globalization, small companies having entered international market through internet, consumer society, and huge spread of information and products. In this changing context, it emphasizes the need of the existence of sophisticated programs assisting the translation of these products, and introduces some of basic terms and tools concerning technology and translation areas, like eXtensible Markup Language (XML), Controlled Language (CL), Machine Translation (MT), Computer-Aided Translation (CAT), Translation Memory (TM) or others.

Hartley brings significant concepts to Translation Studies, allowing "the meta-discussion begin" to use Holmes's expression. Among them are terms like internationalization, localization and globalization. After having introduced some of translation tools, the contributor concludes his article arguing that they merit assessment for the benefit they bring to the field, specifically three of them: determining whether a tool is fit for purpose, tracking its performance on different kinds of data, and measuring its cost-effectiveness over time.

Chapter Eight, Pöchhacker's Issues in Interpreting Studies, explores the position of interpreting studies within the broader discipline of Translation Studies as ambiguous. It highlights diversification in interpreting as both professional practice and research object, which has given rise to many new areas of interdisciplinary interface, thus making it even more difficult to accommodate interpreting studies within the boundaries, however fuzzy, of translation studies. Along with presenting academic foundations and ways running through the area even today, Pöchhacker's article claims that interpreting has been expressly open to all areas of interpreting, including court interpreting, community interpreting and signed language interpreting. He covers a conceptual spectrum of interpreting, emphasizing the twofold distinction between international versus community-based interpreting, and between conference and liaison interpreting.

Additionally, he presents one section with some of the thematic focal points of research in interpreting studies, talking about cognitive processing, quality, training, ethics and role, technology and history. And closes his essay saying that, across its various paradigms, interpreting studies has built up a rather extensive conceptual and methodological repertoire that includes cognitivepsychological experiments, corpus-linguistic quantification, web-based surveys, sociolinguistic discourse analysis, sociological modeling of institutions and interaction, and ethnographic work inspired by cultural anthropology.

The final chapter, Chiaro's Issues in Audiovisual Translation, deals with both the concept and the situation of audiovisual translation, in special with media translation, multimedia translation, multimodal translation and screen translation (especially dubbing and subtitling - process, advantages and disadvantages). It introduces some news in the dubbing and subtitling area. In the dubbing scenario, for example, Chiaro insists that new technology helps modifying lip sync or voice 
quality, and software is now available to provide automatic footage modification, helping an actor to mouth words that he or she did not actually speak in the original.

With regard to subtitling, speech recognition software is able to transform oral speech into written subtitles with a certain degree of accuracy. Citing Antonini (2005), Chiaro deals with the three major operations - elimination, rendering and simplification - that the translator must carry out in order to obtain effective subtitles. Chiaro closes her article emphasizing that new technologies can indeed speed up the processes of dubbing and subtitling. However she calls attention to the quality of the translation itself as something so crucial that no subtitling and dubbing software imaginable can replace.

Translation readers of all kinds - students, practitioners and scholars - will profit from the reading of this volume, finding in it answers to potential and crucial questions and advancements to their investigative needs. The extensive selection of articles on translation and related areas has covered academic thinkers from both historic and contemporary periods and backgrounds, whose insightful thoughts and analytical contributions have greatly impacted on Translation Studies. The variety of issues will provide the readers with an invaluable theoretical and practical picture of the field of translation studies and their adjacent areas like cultural, linguistic and post-colonial studies, just to mention some of them, which recur in the contributors' words.

Janine Oliveira José Endoença Martins

Orlanda Miranda Santos Universidade Federal de Santa Catarina (UFSC), Florianópolis, Brazil.

\section{RÉFÉRENCES}

BAKer, Mona and SAldanha, Gabriela, eds. (2008): Routledge Encyclopedia of Translation Studies, $2^{\text {nd }}$ ed., London: Routledge.

Lefevere, André (2007): Tradução, Reescrita e Manipulação da Fama Literária. (Translated by Cláudia Matos Seligmann) Bauru, SP: Edusp.

Morrison, Toni (1984): Rootedness: The Ancestor as Foundation. In: Mari Evans, ed. Black Women Writers (1950-1980): A Critical Evaluation. New York: Anchor Books, 339-345.

Navarro Domínguez, Fernando et al. (dir.) (2008): La traducción: balance del pasado y retos del futuro. Alicante: Editorial Aguaclara y Département de traduction et d'interprétation de l'Université d'Alicante, 511 p.
Alicante, capitale de la province homonyme, est la deuxième ville la plus importante de la communauté valencienne dans le sud-est de l'Espagne. Cette communauté est, avec la région autonome de la Catalogne, et les îles Baléares, un des trois territoires catalophones autonomes d'Espagne ${ }^{1}$. La question linguistique revêt donc une importance marquée dans cette région.

De l'Université d'Alicante, qui compte un département de traduction et d'interprétation depuis 2007, nous connaissons la collection MONTI Monographies de Traduction et d'Interprétation, publiée en cinq langues (espagnol, catalan, anglais, français et allemand) depuis 2009 en collaboration avec les deux autres universités publiques de la région, à savoir : l'Université Jaume-I et l'Université de Valence.

L'ouvrage dont il est question ici est antérieur à cette collection et peut dès lors être considéré comme l'opera prima d'un groupe de traductologues espagnols désireux de diffuser leurs travaux. Dans ce volume, ils font en outre appel à des auteurs reconnus au niveau international. Le Canada se trouve en tête avec un article de Georges L. Bastin, sur la pédagogie de la traduction. Alexis Nouss, qui enseigne maintenant à Cardiff, mais dont le nom a longtemps été associé à l'Université de Montréal, est également présent dans le premier bloc de textes intitulé: "De la visión histórica a los nuevos retos en traducción e interpretación». L'article de Nouss pose la question, fondamentale, de savoir «comment la traductologie définit ses objectifs et ses méthodes d'analyse».

Lawrence Venuti, Mourad Zarrouk, de l'Université de Grenade en Espagne et de l'École Supérieure Roi Fahd de Tanger, ainsi que Teresa Tomaszkiewicz, de l'Université Adam Micikiewicz de Poznan en Pologne, sont les trois autres auteurs «internationaux» invités à participer à ce recueil de textes auquel ont également collaboré «des chercheurs, des professeurs, des professionnels et des étudiants espagnols ".

La formation des traducteurs, mais aussi les outils didactiques, la traduction littéraire, la traduction spécialisée et l'histoire de la traduction sont traités dans cet ouvrage à thèmes très variés. À la première partie qui présente le texte des auteurs invités et celui de deux des directeurs de l'ouvrage, s'ajoute une deuxième partie subdivisée en quatre chapitres consacrés aux thèmes mentionnés cidessus. Les contributions proviennent d'auteurs associés pour la plupart à l'Université d'Alicante. Suivent l'Université de Grenade et six autres universités espagnoles. Figurent également des textes en provenance d'universités du Pérou, du Costa Rica et d'Allemagne. Les contributions, quoique portant essentiellement sur l'Espagne et l'Europe occidentale, font des allers-retours dans d'autres 